\title{
Winter sea ice export from the Laptev Sea preconditions the local summer sea ice cover and fast ice decay
}

\author{
Polona Itkin ${ }^{1,2}$ and Thomas Krumpen ${ }^{1}$ \\ ${ }^{1}$ Alfred Wegener Institute, Helmholtz Center for Polar and Marine Research, Bremerhaven, Germany \\ ${ }^{2}$ Norwegian Polar Institute, Troms $\varnothing$, Norway \\ Correspondence to: Thomas Krumpen (thomas.krumpen@awi.de)
}

Received: 27 February 2017 - Discussion started: 15 March 2017

Revised: 19 July 2017 - Accepted: 20 July 2017 - Published: 23 October 2017

\begin{abstract}
Ice retreat in the eastern Eurasian Arctic is a consequence of atmospheric and oceanic processes and regional feedback mechanisms acting on the ice cover, both in winter and summer. A correct representation of these processes in numerical models is important, since it will improve predictions of sea ice anomalies along the Northeast Passage and beyond. In this study, we highlight the importance of winter ice dynamics for local summer sea ice anomalies in thickness, volume and extent. By means of airborne sea ice thickness surveys made over pack ice areas in the southeastern Laptev Sea, we show that years of offshore-directed sea ice transport have a thinning effect on the late-winter sea ice cover. To confirm the preconditioning effect of enhanced offshore advection in late winter on the summer sea ice cover, we perform a sensitivity study using a numerical model. Results verify that the preconditioning effect plays a bigger role for the regional ice extent. Furthermore, they indicate an increase in volume export from the Laptev Sea as a consequence of enhanced offshore advection, which has far-reaching consequences for the entire Arctic sea ice mass balance. Moreover we show that ice dynamics in winter not only preconditions local summer ice extent, but also accelerate fast-ice decay.
\end{abstract}

\section{Introduction}

The Laptev Sea became almost completely ice free during summertime in the past years. Similar conditions in the other Siberian seas (Kara, East Siberian and Chukchi Sea) facilitate ship transport conducted without the support of icebreakers through the Northeast Passage from Europe to east- ern Asia. Ice retreat in the Laptev Sea is the consequence of atmospheric and oceanic processes and regional feedback mechanisms acting on the ice cover. During summer, local anomalies in sea ice extent are thought to be controlled by synoptic-scale processes (e.g. cyclones) superimposed on the large-scale atmospheric circulation (Bareiss and Görgen, 2005). The connection between shifts in the atmospheric circulation and the role of cyclonicity for anomalies in summer sea ice concentration were discussed by Serreze et al. (1993), Serreze (1995), Maslanik et al. (1996) and Maslanik et al. (2000). In particular cyclones entering the Laptev Sea from the south-west enhance the northward ice transport and are associated with an inflow of anomalous warm air masses of above-average air temperatures. If ice retreat happens early enough to allow atmospheric warming of this open water (e.g. during years of high export), winds that force ice floes back into this water cause melting. The interaction between surface winds and warm sea surface temperatures in areas from which the ice has already retreated were recently investigated by Steele and Ermold (2015). During winter, anomalous high temperatures reduce sea ice growth of firstyear ice, resulting in a thinner ice cover at the end of April (Ricker et al., 2017). In addition, enhanced winter ventilation of the ocean reduces sea ice formation at a rate now comparable to losses from atmospheric thermodynamic forcing (Polyakov et al., 2017). Observations carried out in the eastern Eurasian Basin have shown that weakening of the halocline and shoaling of intermediate-depth Atlantic water layer results in heat flux equivalent to $40-54 \mathrm{~cm}$ reductions in ice growth in 2013/2014 and 2014/2015. The winter preconditioning of the summer sea ice cover has been lately used by Kimura et al. (2013) to develop a summer sea ice outlook 


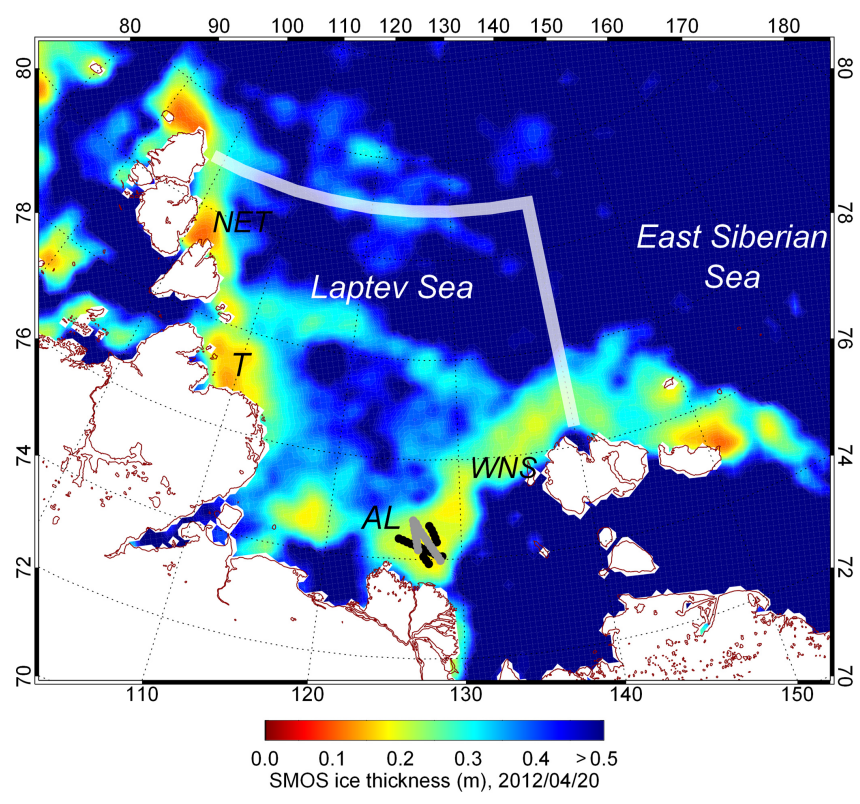

Figure 1. The Laptev Sea and the northern and eastern boundaries (white lines) on which satellite- and model-derived sea ice export estimates are based. Colour coding corresponds to the sea ice thickness as obtained from the Soil Moisture Ocean Salinity (SMOS) satellite on 20 April 2012 (source: University Hamburg, Tian-Kunze et al., 2017). The black and grey line show the flight path of EMBird ice thickness measurements made during the April 2008 (TD XIII) and April 2012 (TD XX) campaign, respectively. The approximate positions of prominent polynyas are indicated: the West New Siberian polynya (WNS), the Anabar Lena polynya (AL), the Taymyr (T) polynya, and the north-eastern Taymyr (NET) polynya.

based on the winter sea ice motion. Locally in the Laptev Sea, the major source area of the Transpolar Drift, the recent study of Krumpen et al. (2013) showed a high statistical connection of the late-winter (February-May) sea ice export through the northern and eastern boundary to the summer sea ice concentration. This suggests that years of high ice export in late winter have a thinning effect on the ice cover, which in turn preconditions the occurrence of negative sea ice extent anomalies in summer and vice versa.

A correct representation of the above-described processes in numerical models will improve predictions of sea ice anomalies along the Northeast Passage and beyond. To improve understanding of individual mechanisms contributing to sea ice decline, in this study we further investigate the hypothesis about the preconditioning effect of winter ice dynamics on the local summer sea ice cover. To separate the winter from the summer processes that influence the summer sea ice cover in the Laptev Sea, we perform a sensitivity study by means of a numerical model. This allows us to quantify this effect and to test whether the observed increase sea ice area export is reflected in an increase in sea ice volume export out of the Laptev Sea. This would extend the impor- tance of the regional sea ice transports to the larger region of the Transpolar Drift system.

The outline of this paper is as follows. In Sect. 2 we describe the observational and satellite data sources, and the numerical model. In Sect. 3, we review the preconditioning effect of late-winter ice dynamics on the sea ice cover by means of airborne sea ice thickness surveys made at the end of the winter 2008 and 2012. In Sect. 4, we extend the latewinter sea ice export of Krumpen et al. (2013) to 2014 and compare satellite-based estimates with results obtained from the numerical model. Finally, we investigate the importance of the winter preconditioning for the summer sea ice cover in a sensitivity study (Sect. 5). In Sects. 6 and 7 we discuss and sum up our findings and investigate the impact of winter ice dynamics on fast ice decay.

\section{Data}

Satellite- and model-based sea ice area export out of the Laptev between February and May are calculated using ice drift velocities and ice concentration information obtained at the northern (NB) and eastern boundary (EB) of the study area (Fig. 1). The NB spans a length of $700 \mathrm{~km}$ and is positioned at $81^{\circ} \mathrm{N}$, between Komsomolets Island and $140^{\circ} \mathrm{E}$. The EB with a length of $460 \mathrm{~km}$, connects the eastern end of the NB with Kotelnyy Island $\left(76.6^{\circ} \mathrm{N}, 140^{\circ} \mathrm{E}\right)$. Following Krumpen et al. (2013), the sea ice flux is the sum of the NB and EB flux, which is the integral of the product between the $v$ and $u$ components of the ice drift and ice concentration. The volume flux is calculated in a similar way, but replacing the sea ice concentration with the sea ice thickness. Note that in this study a positive (negative) flux refers to an export out of (import into) the Laptev Sea.

\subsection{Satellite-based ice area export}

The applied ice drift and concentration data is provided by the European Space Agency (ESA) via the Center for Satellite Exploitation and Research (CERSAT) at the Institut Francais de Recherche pour d'Exploitation de la Mer (IFREMER), France. The motion fields are based on a combination of drift vectors estimated from scatterometer (SeaWinds/QuikSCAT and ASCAT/MetOp) and radiometer (Special Sensor Microwave Imager, SSM/I) data. They are available with a grid size of $62.5 \mathrm{~km}$ and have a temporal resolution of 3 days. The applied concentration product is provided by the same organization and is based on $85 \mathrm{GHz}$ SSM/I brightness temperatures, using the ARTIST Sea Ice (ASI) algorithm. The product is available on a $12.5 \mathrm{~km} \times 12.5 \mathrm{~km}$ grid (Ezraty et al., 2007). A comparison with ice drift information obtained from Environmental Satellite (ENVISAT) synthetic aperture radar (SAR) images and long-term moorings equipped with acoustic Doppler current profilers (ADCP) have shown that accuracy of the 
of IFREMER motion data is high and the uncertainty in the ice area export is around $81 \times 10^{3} \mathrm{~km}^{2}$ for the NB and $57 \times 10^{3} \mathrm{~km}^{2}$ for the EB over the entire winter (OctoberMay) (Rozman et al., 2011; Krumpen et al., 2013). For more detail about the applied ice drift and concentration products we refer to Ezraty et al. (2007), Girard-Ardhuin and Ezraty (2012), Krumpen et al. (2016).

\subsection{Airborne ice thickness data}

Within the framework of the Russian-German research cooperation Laptev Sea System, two helicopter-based electromagnetic (HEM) ice thickness surveys were made in the south-eastern Laptev Sea at the end of April 2008 (campaign TD XIII) and 2012 (campaign TD XX, Fig. 1). The measurements made over pack ice zones north of the landfast ice edge were used to estimate sea ice production in flaw polynyas (Rabenstein et al., 2013; Krumpen et al., 2011) and for validation of ESA's SMOS (Soil Moisture Ocean Salinity) satellite derived ice thickness products (Huntemann et al., 2014; Tian-Kunze et al., 2014, 2017). Flaw polynyas are open water sites between pack ice and fast ice of high net ice production sustained by winds. For a detailed description of the HEM principle we refer to (Haas et al., 2009; Krumpen et al., 2016). In short, the instrument that is towed by a helicopter $15 \mathrm{~m}$ above the ice surface utilizes the contrast of electrical conductivity between sea water and sea ice to determine its distance to the ice-water interface. An additional laser altimeter yields the distance to the uppermost snow surface. The difference between the laser and HEM derived distance is the ice plus snow thickness. According to Pfaffling et al. (2007), the accuracy over level sea ice is of the order of $\pm 10 \mathrm{~cm}$.

\subsection{Model}

The numerical model used in this study is a regional coupled sea-ice-ocean model based on the Massachusetts Institute of Technology General Circulation Model code - MITgcm (Marshall et al., 1997; MITgcm Group, 2014) with a model domain covering the Arctic Ocean, Nordic seas and northern North Atlantic. The horizontal resolution is $1 / 4^{\circ}(\sim 28 \mathrm{~km})$ on a rotated grid with the grid equator passing through the geographical North Pole. The sea ice model is a dynamicthermodynamic sea-ice model with a viscous plastic rheology (Losch et al., 2010) and has a landfast ice parameterization as described by Itkin et al. (2015), in which more details about the model set-up can be found. The model is forced by the atmospheric reanalysis - The Climate Forecast System Reanalysis (Saha, 2010, NCEP-CFSR) from 1979 to 2010 and then from 2011 to 2014 with the NCEP Climate Forecast System Version 2 (Saha, 2014, CFSv2). The selection of the NCEP-CFSR atmospheric forcing is based on the low biases compared to other atmospheric reanalysis (Lindsay et al., 2014). Itkin et al. (2014) compared sea ice con- centration, thickness and drift speed of a similar model setup without landfast ice parameterization to satellite observations. They reported that the model overestimates the summer sea ice concentration in the shelf seas compared to the OSI-SAF sea ice concentration product (OSI-SAF, 2013). Compared to the ICESat sea ice thickness (Zwally et al., 2002) the model reproduces the regional sea ice thickness distribution well, but it tends to overestimate the winter sea ice thickness on the Siberian shelf seas. A comparison to the CERSAT and NSIDC sea ice drift products (Girard-Ardhuin and Ezraty, 2012; Tschudi et al., 2016) showed that the sea drift speeds in the model fall within the uncertainty of the drift products with the exception of very high drift velocities that are overrepresented by the model. Adding the landfast ice parameterization reduces the sea ice thickness bias on the shelf and partially slows down the drift speeds in the same region (Itkin et al., 2015). Despite the biases the model performance is reasonably good and can give reliable results in sensitivity studies used for demonstrating process mechanisms and feedback directions.

\section{Preconditioning of summer ice extent by winter ice dynamics}

The preconditioning effect of late-winter ice export on local ice cover in the following summer was investigated by Krumpen et al. (2013). A comparison of satellite-based latewinter ice flux with summer ice anomalies revealed a negative coupling with a correlation coefficient of $r=-0.65$. The negative correlation of late-winter sea ice export from the Laptev Sea and subsequent summer sea ice concentration can be explained by the replacement of the exported ice by new ice formed in polynyas situated along the landfast ice edge. Note that there is a close relationship $(r=0.85)$ between across-boundary ice export and estimated polynya area (Krumpen et al., 2013, compare Fig. 12), because offshore wind favours both ice transport away from the coast and the development of thin ice in flaw polynyas. If new ice zones are formed comparatively late and ice motion is dominated by an offshore-directed drift component, new ice areas stay rather thin and may melt more rapidly once temperatures rise above freezing. In contrast, new ice zones formed during winters with enhanced onshore advection of sea ice are subject to a stronger dynamic thickening which in turn delays the onset of sea ice retreat.

While sea ice thickness observations in the Laptev Sea that could confirm this preconditioning mechanism are scarce, HEM ice thickness measurements (Fig. 2) were taken during two contrasting years of late-winter sea ice export. In our simulation as well as in the satellite-based data, the sea ice export in winter 2008 was lower than average, while 2012 was characterized by an above-average export (see Sect. 4). Flights that were made in 2008 (14, 16 and 24 April) cover much thicker ice with a mean thickness of $2.7 \mathrm{~m}$. The thick- 


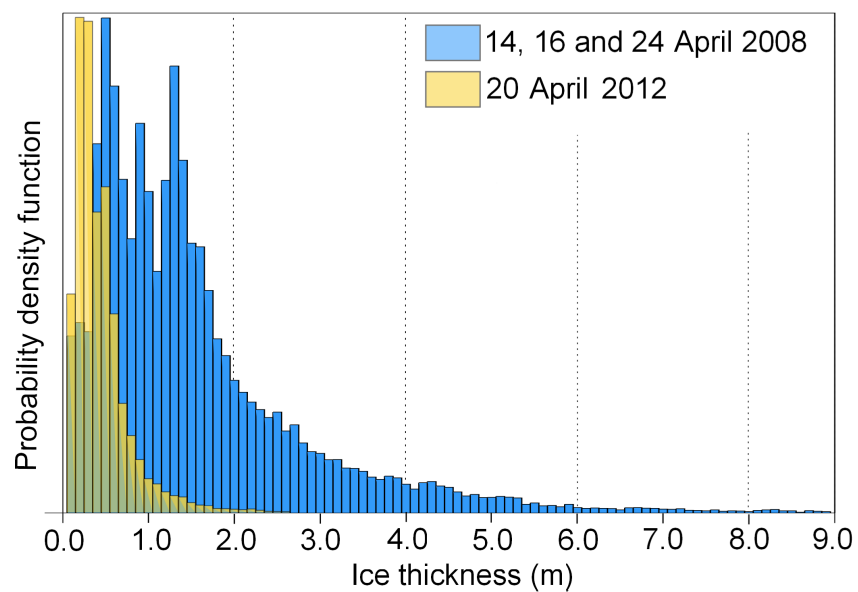

Figure 2. Ice thickness distributions obtained from HEM measurements made offshore the landfast ice edge during the TD XIII campaign (blue: 14, 16 and 24 April 2008) and TD XX (yellow: 20 April 2012) campaign. The positions of the measurements are indicated in Fig. 1

ness distribution shows two modes: one at $0.5 \mathrm{~m}$ and another one at $1.5 \mathrm{~m}$. Following Rabenstein et al. (2013), the ice was originally formed in polynyas in the south-eastern part of the Laptev Sea, but was heavily compacted during a longer period of onshore-directed ice drift in late winter. Due to the presence of a compact ice cover in near shore areas, ice retreat took place relatively late in the season and large parts of the Laptev Sea remained ice covered during summer (Fig. 3, left panel). In contrast, HEM measurements that were made on 20 April 2012 cover a substantially different ice regime: the winter of 2011/2012 was characterized by the second highest northward advection rates observed since 1992 (compare Fig. 4). As a consequence, the continuous ice export away from the landfast ice edge led to the development of an almost $200 \mathrm{~km}$-wide thin ice zone of less than $40 \mathrm{~cm}$ ice thickness. Ice thickness estimates obtained from the SMOS satellite (Fig. 1, data source Tian-Kunze et al., 2017) confirm the presence of large thin ice zones all along the landfast ice edge. It stands to reason that the presence of thin ice preconditioned early sea ice retreat (Fig. 3, right panel) and contributed to the low summer ice extent in the Laptev Sea. Note that the date of sea ice retreat for 2008 and 2012 was estimated using IFREMER ice concentration data at each grid point and defined as the first day in a series of at least 7 days with a sea-ice concentration of less than $15 \%$. For more detail we refer to Janout et al. (2016).

\section{Model and satellite data intercomparison}

Before investigating the impact of winter ice dynamics on summer ice conditions with the model, its performance was examined via a comparison of simulated versus satellite-based ice export and extent. Figure 4 presents

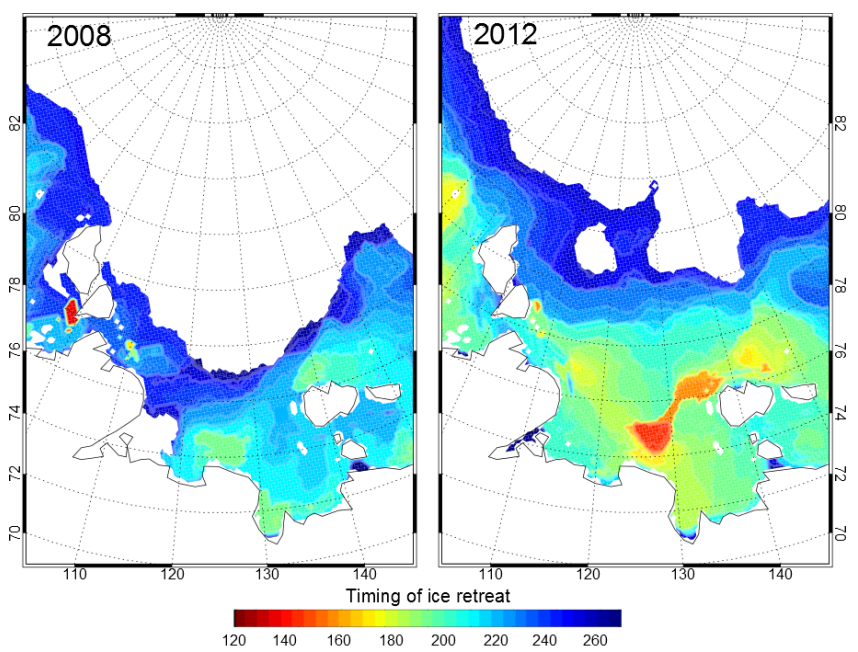

Figure 3. Timing (day of the year) of sea ice retreat in the Laptev Sea in spring 2008 and 2012. The onset of ice retreat is defined as the first day in a series of at least 7 days with a sea ice concentration of zero (Janout et al., 2016).

observed (panel a) and simulated (panel b) winter sea ice export (February-May) and summer ice extent (AugustSeptember). Both model- and satellite-based estimates show large interannual variability in export and summer ice coverage. Following Krumpen et al. (2013), the variability is primarily controlled by changes in geostrophic wind. The positive trend in observed ice export of $7.19 \times 10^{3} \mathrm{~km}^{2}$ year ${ }^{-1}$ $(p=0.0049)$ is, however, associated to an increasing drift speed, likely being the consequence of a change in the ice cover (thinning and/or decreasing concentration) caused by the rapid loss and thinning of thick multiyear ice (Haas et al., 2008). The trend in simulated export rates is higher $\left(12.02 \times 10^{3} \mathrm{~km}^{2}\right.$ year $\left.^{-1}\right)$ and statistically significant at $91 \%$ confidence level $(p=0.0888)$. The overall agreement between simulations and observations is high, with a correlation coefficient of 0.33 for the late-winter sea ice exports and 0.81 for the summer sea ice concentrations. Unfortunately, sea ice volume flux estimates covering the entire investigation period are not available from observations due to the lack of the sea ice thickness measurements. However, the model simulation shows that the volume export is highly correlated to the area flux $(r=0.98)$, and has a positive trend of $19.8 \mathrm{~km}^{3}$ year $^{-1}$ (not significant, $p=0.1729$ ). Despite the good agreement, the simulated sea ice area export and summertime ice concentration are much higher than the satellitebased estimates. The averaged simulated sea ice concentration during summer and ice export during winter amount to $47 \%( \pm 16 \%)$ and $388 \times 10^{3} \mathrm{~km}^{2}\left( \pm 231 \times 10^{3} \mathrm{~km}^{2}\right)$, while averaged satellite-based estimates are $29 \%( \pm 18 \%)$ and $142 \times 10^{3} \mathrm{~km}^{2}\left( \pm 90 \times 10^{3} \mathrm{~km}^{2}\right)$. 


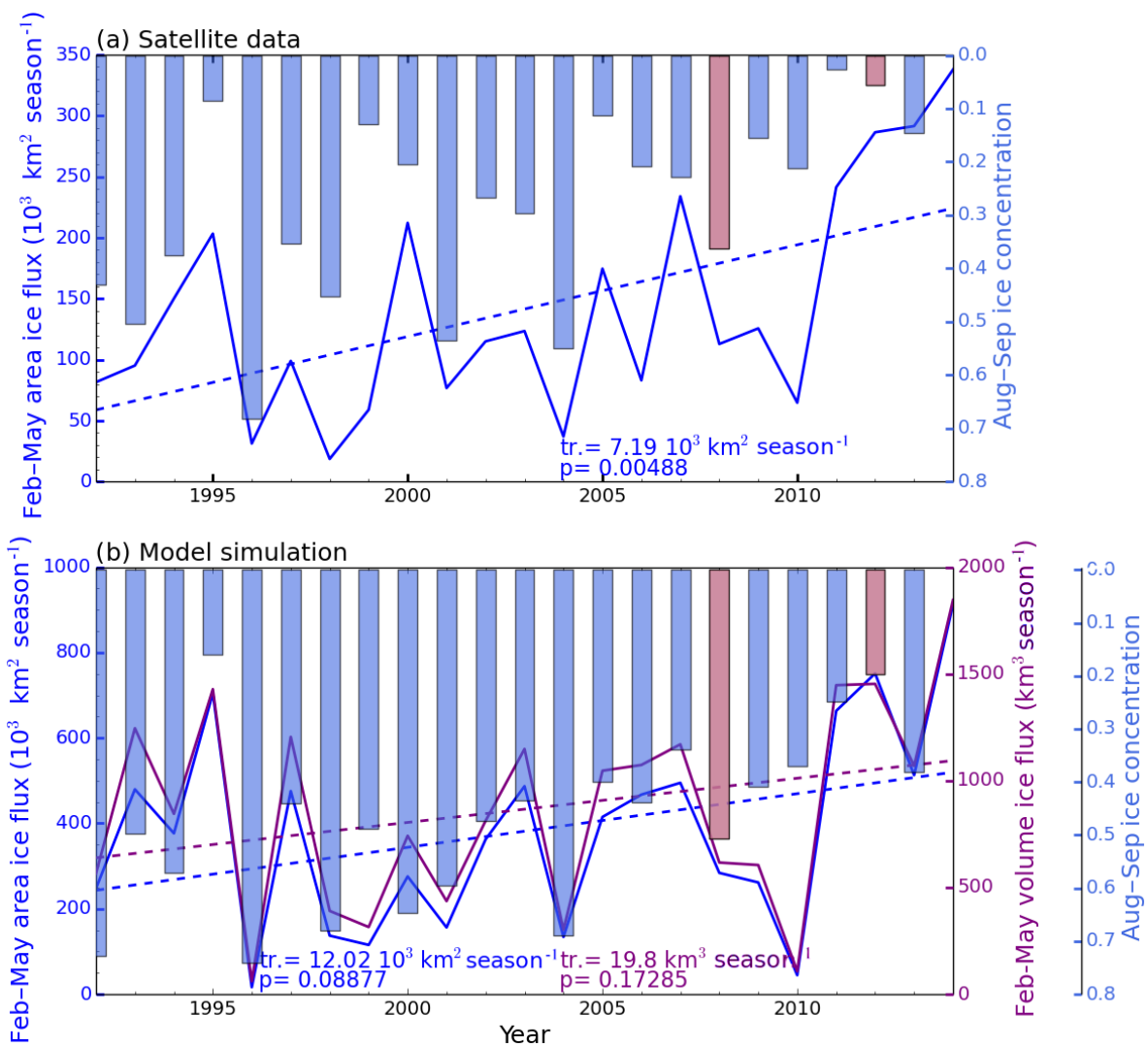

Figure 4. Time series of the late-winter sea ice transport and summer sea ice concentration for the Laptev Sea (closed box inside the northern and eastern boundaries and coastlines): (a) satellite-based estimates, (b) model simulations. Trend lines of ice fluxes are represented by dashed lines. Note that the sea ice concentration axis is inverted to facilitate the comparison. Likewise, the scale of fluxes is not the same on both panels. The correlations between the model and satellite data are provided in text of corresponding colours.

\section{Sensitivity study}

The negative correlation of late-winter sea ice export out of the Laptev Sea and the following summer sea ice concentration are confirmed by our simulation. The correlation coefficient between winter export and summer ice cover of the remote sensing products is -0.65 , while the correlation of simulated variables is even higher $(r=-0.77)$. This indicates that the winter processes preconditioning summer sea ice cover are well captured by the model. Figure 5 a shows the simulated seasonal cycle of sea ice volume fluxes through the Laptev Sea boundaries (Fig. 1) and sea ice growth rates, concentration and volume between 1992 and 2014 in the Laptev Sea. Years of above- and below-average ice export are shown in red and blue, respectively. It is apparent that years of high late-winter ice export result in lower summer ice extent and vice versa. The export also impacts sea ice thickness, and consequently sea ice volume of the Laptev Sea. In the model, sea ice thickness is $30 \%$ lower during years of high export which in turns leads to a reduced sea ice volume and the other way around.
To differentiate between the effects of winter and summer processes preconditioning the ice cover in August and September, we designed a sensitivity study in which the model is forced with the interannual atmospheric reanalysis in winter (January-April). From May to December a climatology (CLIM) is used instead. At the beginning of every year the simulation is continued from a state taken from the control run (CTRL). Figure 5b shows the sea ice concentration and seasonal sea ice volume cycle from 1992-2013 as obtained by the model forced with a climatology between May and December. Results indicate that there is a clear tendency to separate the annual cycles of the sea ice concentration and volume in CTRL, which becomes more pronounced in CLIM. In contrast to CTRL, in CLIM all years with high late-winter sea ice export regime result in low summer sea ice concentration and vice versa. Note that the impact of export strength on sea ice concentration is already apparent in April and May, when years with high late-winter sea ice export have typically lower sea ice concentration compared to years with low sea ice export. Likewise the annual cycle of sea ice thickness is strongly connected to the late-winter export strength. A year that starts with an above-average ice 

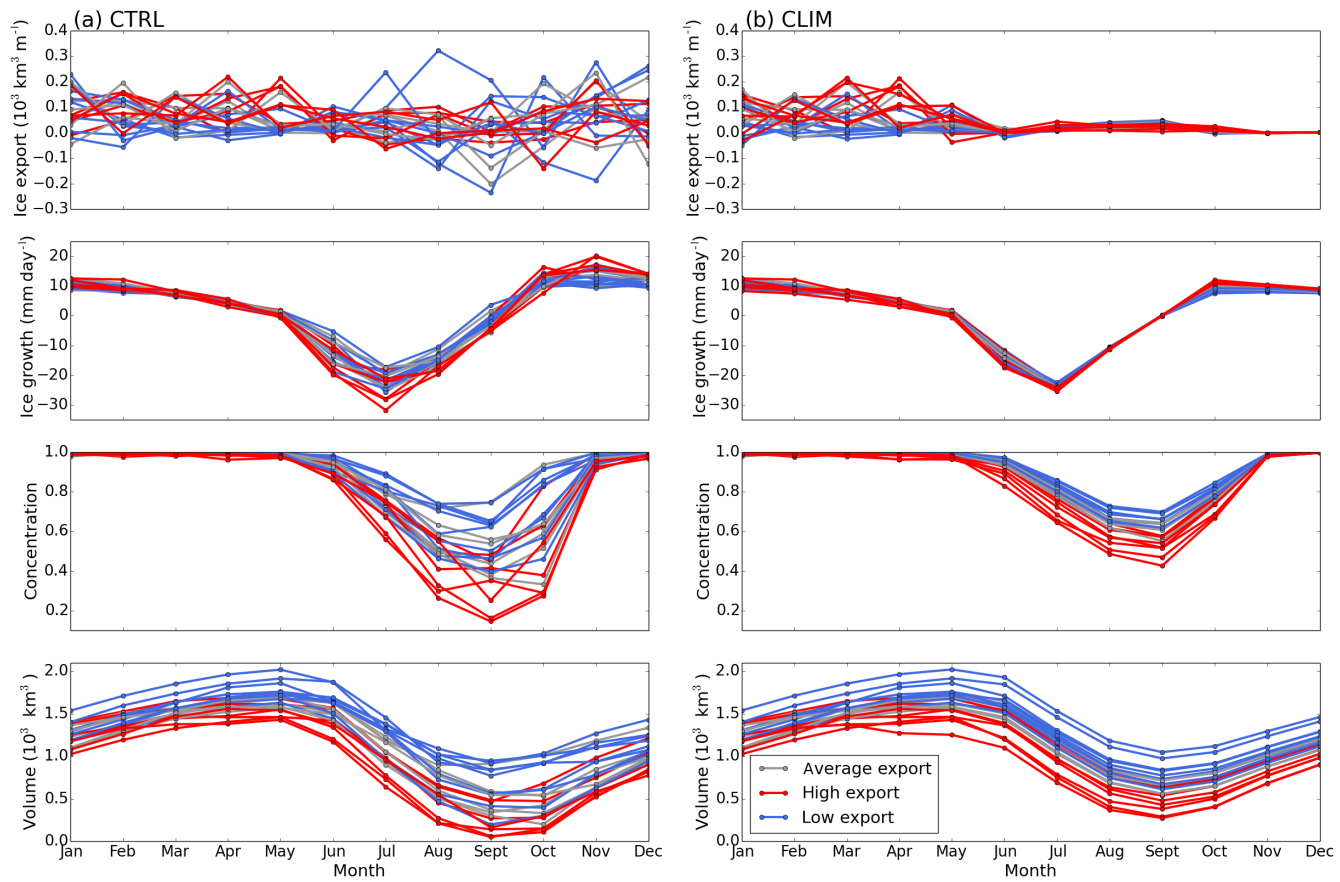

Figure 5. Sea ice exports, growth rates, concentration and volume seasonal cycle (1992-2014) as obtained by the model: (a) control run, (b) model forced with a climatology between May and December. The mean volume sea ice export is $226 \mathrm{~km}^{3}$ season ${ }^{-1}$ and the line colours (grey, red and blue) are used to distinguish between years with average ( $\pm 25 \%$ of the mean), high (above $25 \%$ the mean) and low (bellow $25 \%$ the mean) volume sea ice export.

thickness (high sea ice volume), but has a strong polynya activity in the late winter will have a thinner ice cover (low sea ice volume) in summer. Also the opposite is true. While mean summer (June-August) sea ice exports are similar for both regimes, sea ice concentration and volume differences increase further towards the end of summer. This increase is driven by the melt rates that are on average higher by $17 \%$ (7.5\%) in CTRL (in CLIM) in years with high late-winter exports. This is a clear consequence of the albedo feedback, wherein more open water in the beginning of the summer allows higher absorption of solar energy into the ocean, leading to higher ocean surface temperatures and stronger sea ice bottom melt later in the season. The sea ice bottom melt caused by the ocean heat fluxes is in CLIM on average $27 \%$ higher ( $28 \%$ in CLIM) in the years with high late-winter exports compared to the years with low late-winter exports (not shown separately on the figure). Although years with low summer sea ice concentration have a delayed freeze-up in autumn, the sea ice memory is not preserved beyond the synoptic events driving the sea ice exports in the following late winter.

\section{Discussion}

The negative correlation of observed and simulated latewinter sea ice export from the Laptev Sea and subsequent summer sea ice concentration can be explained by the replacement of the exported ice by new ice formed in polynyas situated along the landfast ice edge. The comparison of the HEM ice thickness measurements obtained in April 2008 and April 2012 over Laptev Sea pack ice indicates the thinning effect of enhanced offshore ice advection on the sea ice cover, resulting in an earlier onset of ice retreat.

The presence of extensive thin ice areas in years with a high late-winter sea ice export preconditions low sea ice extent and volume in the following summer. This connection is confirmed by the model sensitivity study in which we replace the interannual summer atmospheric forcing by a climatology. Although the model is not perfectly tuned to observations (simulated export and summer ice coverage are double of satellite-based estimates), the use of the model for a sensitivity study is sufficiently rigorous, since we expect to provide a zero-order estimate of the potential contribution of winter ice export on summer sea ice cover. In addition, the mismatch between simulated and observed fluxes may be further attributed to an overestimation of wind speed in the reanalysis data. Too-high wind speed in some of the atmospheric forcing data for the Laptev Sea region have already been pointed out by Ernsdorf et al. (2011) and Fofonova et al. (2014), e.g. NCEP-CFSR atmospheric forcing used in this study likely overestimates the wind speeds in the early 1990 s. PIOMAS simulations with various atmospheric forcing show that the simulation with NCEP-CFSR results in a relatively 
low winter sea ice volume in the early 1990s that is comparable to the state in the recent years (Lindsay et al., 2014).

In the model, years with high late-winter sea ice export result in a reduced sea ice cover. In CLIM the effect is even more pronounced. However, note that summer ice concentration and volume in CLIM are about 13 and $32 \%$ larger than in CTRL. The case is similar for the summer sea ice exports and melt rates. In addition, the spread between the years is unrealistically low. Both artefacts are consequences of averaged forcing fields in the CLIM.

\section{Impact on fast ice decay}

New ice zones formed at the end of the winter during offshore advection events rapidly melt once the temperature rises above freezing. It stands to reason that the ice albedo feedback not only accelerates retreat of surrounding sea ice, but also leads to an earlier onset of fast ice decay. The Laptev Sea is characterized by an extensive fast ice extent. The interannual and seasonal variability and trends of the southeastern Laptev Sea fast ice, an area with the widest fast ice extent in the Arctic located between $77^{\circ} \mathrm{N}, 125^{\circ} \mathrm{E}$ and $72^{\circ} \mathrm{N}$, $140^{\circ} \mathrm{E}$, were recently investigated by Selyuzhenok et al. (2015). The authors used operational sea ice charts provided by AARI to determine the onset of fast ice growth, extent, beginning of breakup, and end of the fast ice season between 1999 and 2013. For a detailed description of methods and applied data we refer to Selyuzhenok et al. (2015). The fast ice edge in late spring closely follows the $20-25 \mathrm{~m}$ isobaths indicating that grounded ridges serve as an anchor point for fast ice and hence determine, among other factors, maximal fast ice extent. The onset of fast ice breakup starts near the Lena Delta and is closely correlated to the river breakup (compare Fig. 5 in Selyuzhenok et al., 2015). Mid-June river run-off overfloes fast which leads to a reduction in surface albedo. In addition, it contributes to a direct input of heat. As the fast ice breaks up along the delta, it continues to retreat eastward. Following Bareiss et al. (1999) further decay is controlled by onset of surface melt which was confirmed by Selyuzhenok et al. (2015), who find a strong correlation with the timing of the end of the fast ice season (time when fast ice extent drops below a certain threshold value) and the onset of surface melt derived from passive microwave data. The onset of breakup and end of the fast ice season both show negative trends of -0.3 and -1.0 days year ${ }^{-1}$, respectively. Hence, the time it takes for fast ice to decay is shortening by -1.3 days year ${ }^{-1}$.

How dynamics of pack ice in winter influence fast ice decay has not been studied. Therefore we compare the sea ice export with the timing of fast ice breakup and end of fast ice season obtained from satellite data. We limit the comparison to the south-eastern Laptev Sea, where mechanisms of growth and decay were studied in detail by Selyuzhenok et al. (2015) and accurate information about timing of breakup is available. The correlation coefficient between onset of fast ice breakup and ice area export is small $(r=-0.35)$. This in- dicates that onset of fast ice breakup is independent of winter ice dynamics and, as suggested by Selyuzhenok et al. (2015) and Bareiss et al. (1999), rather attributed to the timing of river breakup. However, the correlation between end of fast ice season and ice export is higher $(r=-0.63)$. Hence, in addition to the onset of surface melt, years of strong offshore advection precondition an earlier end of the fast ice season and shortening of the duration of the breakup period and vice versa. Similarly to the summer drift ice melt mechanism described in Sect. 5 and depicted on Fig. 5, our model shows that during years of high ice export, sea ice concentration has already been relatively low since May and the melt rates are also elevated for a spatially more confined region in the SE Laptev Sea. While the model does not resolve the grounded pressure ridges that form the anchor points for the fast ice, we argue that eroding the keels of the grounded ridges would accelerate the fast ice retreat in spring. The tendency towards earlier fast ice retreat may therefore not only be related to rising temperatures in spring and earlier onset of surface melt, but also to the acceleration of pack ice drift and increased offshore advection.

\section{Conclusions}

Our findings highlight the importance of sea ice dynamics in winter for summer sea ice conditions in the Laptev Sea and likewise in the adjacent Siberian seas, where large polynya systems develop in winter (Preußer et al., 2016). Here we show for the first time the thinning effect of winter offshore winds that open polynyas at fast ice edge by means of airborne thickness measurements carried out in 2008 and 2012. The new sea ice grown in polynyas relatively late in the season stays rather thin and becomes subject to quick summer melt, which initiates early ice retreat and low summer sea ice concentration in the Laptev Sea. To confirm the preconditioning of the summer sea ice cover with the winter exports we perform a sensitivity study in which we force our model with interannual atmospheric forcing from January to May and then switch to the climatological forcing until the end of the year. Our results show a clear distinction between years with high and low sea ice export: years with high late-winter sea ice export are characterized by a thinner ice cover and reduced ice volume. The thinner ice cover melts faster which leads to the development of large open water zones that heat up quickly. In addition, model simulations indicate that the volume export from Laptev Sea is increasing and the thinning of the ice cover cannot compensate for the enhanced area export. This provides evidence that the advection of sea ice out of the Laptev Sea has a stronger preconditioning effect than the thickness of the ice cover itself. Ergo increase in the sea ice drift speed, as observed on all Siberian shelf seas (Spreen et al., 2011), plays a bigger role for the regional ice extent in summer than changes in the thickness of the ice cover. Moreover satellite and model data indicate that ice 
dynamics in winter not only preconditions local summer ice extent, but also accelerate fast ice decay.

The mechanism presented in this paper complements earlier studies of Steele and Ermold (2015), Polyakov et al. (2017), Ricker et al. (2017) investigating the declining ice cover in the eastern Eurasian Basin. Here we highlight the importance of winter ice dynamics for sea ice anomalies of thickness, volume and extent in addition to atmospheric processes acting on the ice cover in winter and summer.

Data availability. The data from the HEM ice thickness surveys from campaigns TD XIII and TD XX are available at: https://doi.org/10.1594/PANGAEA.880357 (Krumpen, 2017).

The MITgcm model code and sea ice output are available at https://doi.org/10.1594/PANGAEA.880254 (Itkin and Losch, 2017).

Competing interests. The authors declare that they have no conflict of interest.

Acknowledgements. We acknowledge Valeria Selyuzhenok (Nansen International Environmental and Remote Sensing Centre, St. Petersburg) for providing us with data on fast ice breakup and Christian Haas (Alfred Wegener Institute) for his valuable comments. This work was carried out as part of the Russian-German cooperation QUARCCS and CATS, funded by the BMBF under grant 03F0777A and 63A0028B, the CORESAT project funded by the Norwegian Research Council (grant 222681), the Alfred Wegener Institute, the Norwegian Ministry of Foreign Affairs. Position of PI at the Norwegian Polar Institute was supported through ID Arctic project (funded the by Norwegian Ministries of Foreign Affairs and Climate and Environment, programme Arktis 2030). We are very grateful to two anonymous reviewers and the editor, Jennifer Hutchings, whose valuable comments helped to substantially improve the manuscript.

Edited by: Jennifer Hutchings

Reviewed by: two anonymous referees

\section{References}

Bareiss, J. and Görgen, K.: Spatial and temporal variability of sea ice in the Laptev Sea: Analyses and review of satellite passive-microwave data and model results, 1979 to 2002, Global Planet. Change, 48, 28-54, https://doi.org/10.1016/j.gloplacha.2004.12.004, 2005.

Bareiss, J., Eicken, H., Helibig, A., and Martin, T.: Impact of river discharge and regional climatology on the decay of sea ice in the Laptev Sea during spring and early summer, Arctic Antarctic Alp. Res., 31, 214-229, https://doi.org/10.2307/1552250, 1999.

Ernsdorf, T., Schröder, D., Adams, S., Heinemann, G., Timmermann, R., and Danilov, S.: Impact of atmospheric forcing data on simulations of the Laptev Sea polynya dynamics using the sea- ice ocean model FESOM, J. Geophys. Res.-Oceans, 116, c12038, https://doi.org/10.1029/2010JC006725, 2011.

Ezraty, R., Girard-Ardhuin, F., Piollé, J. F., Kaleschke, L., and Heygster, G.: Arctic and Antarctic Sea Ice Concentration and Arctic Sea Ice Drift Estimated from Special Sensor Microwave Data, Département d'Océanographie Physique et Spatiale, IFREMER, Brest, France and University of Bremen, Germany, 2.1st Edn., available at: ftp://ftp.ifremer.fr/ifremer/cersat/ products/gridded/psi-drift/documentation/ssmi.pdf (last access: 1 August 2014), 2007.

Fofonova, V., Androsov, A., Danilov, S., Janout, M., Sofina, E., and Wiltshire, K.: Semidiurnal tides in the Laptev Sea Shelf zone in the summer season, Cont. Shelf Res., 73, 119-132, https://doi.org/10.1016/j.csr.2013.11.010, 2014.

Girard-Ardhuin, F. and Ezraty, R.: Enhanced Arctic sea ice drift estimation merging radiometer and scatterometer data, IEEE T. Geosci. Remote, 50, 2639-2648, 2012.

Haas, C., Pfaffling, A., Hendricks, S., Rabenstein, L., Etienne, J. L., and Rigor, I.: Reduced ice thickness in Arctic Transpolar Drift favors rapid ice retreat, Geophys. Res. Lett., 35, 17, https://doi.org/10.1029/2008GL034457, 2008.

Haas, C., Lobach, J., Hendricks, S., Rabenstein, L., and Pfaffling, A.: Helicopter-borne measurements of sea ice thickness, using a small and lightweight, digital EM system, J. Appl. Geophys., 67, 234-241, 2009.

Huntemann, M., Heygster, G., Kaleschke, L., Krumpen, T., Mäkynen, M., and Drusch, M.: Empirical sea ice thickness retrieval during the freeze-up period from SMOS high incident angle observations, The Cryosphere, 8, 439-451, https://doi.org/10.5194/tc-8-439-2014, 2014.

Itkin, P. and Losch, M.: MITcgm numerical model code (with landfast ice parametrization) and output, PANGAEA, https://doi.org/10.1594/PANGAEA.880254, 2017.

Itkin, P., Karcher, M., and Gerdes, R. Ü.: Is weaker Arctic sea ice changing the Atlantic water circulation?, J. Geophys. Res.-Oceans, 119, 5992-6009, https://doi.org/10.1002/2013JC009633, 2014.

Itkin, P., Losch, M., and Gerdes, R.: Landfast ice affects the stability of the Arctic halocline: Evidence from a numerical model, J. Geophys. Res.-Oceans, 120, 2622-2635, https://doi.org/10.1002/2014JC010353, 2015.

Janout, M., Hölemann, J., Waite, A., Krumpen, T., von Appen, W., and Martynov, F.: Sea-ice retreat controls timing of summer plankton blooms in the Eastern Arctic Ocean, Geophys. Res. Lett., 43, 12493-12501, https://doi.org/10.1002/2016GL071232, 2016.

Kimura, N., Nishimura, A., Tanaka, Y., and Yamaguchi, H.: Influence of winter sea-ice motion on summer ice cover in the Arctic, Polar Res., 32, 20193, https://doi.org/10.3402/polar.v32i0.20193, 2013.

Krumpen, T.: Sea ice thickness and sea ice area transport in the Laptev Sea, PANGAEA, https://doi.pangaea.de/10.1594/ PANGAEA.880357, 2017.

Krumpen, T., Hölemann, J. A., Willmes, S., Morales Maqueda, M. A., Busche, T., Dmitrenko, I. A., Gerdes, R., Haas, C., Heinemann, G., Hendricks, S., Kassens, H., Rabenstein, L., and Schröder, D.: Sea ice production and water mass modification in the eastern Laptev Sea, J. Geophys. Res.-Oceans, 116, c05014, https://doi.org/10.1029/2010JC006545, 2011. 
Krumpen, T., Janout, M., Hodges, K. I., Gerdes, R., GirardArdhuin, F., Hölemann, J. A., and Willmes, S.: Variability and trends in Laptev Sea ice outflow between 1992-2011, The Cryosphere, 7, 349-363, https://doi.org/10.5194/tc-7-349-2013, 2013.

Krumpen, T., Gerdes, R., Haas, C., Hendricks, S., Herber, A., Selyuzhenok, V., Smedsrud, L., and Spreen, G.: Recent summer sea ice thickness surveys in Fram Strait and associated ice volume fluxes, The Cryosphere, 10, 523-534, https://doi.org/10.5194/tc10-523-2016, 2016.

Lindsay, R., Wensnahan, M., Schweiger, A., and Zhang, J.: Evaluation of Seven Different Atmospheric Reanalysis Products in the Arctic, J. Climate, 27, 2588-2606, https://doi.org/10.1175/JCLID-13-00014.1, 2014

Losch, M., Menemenlis, D., Campin, J.-M., Heimbach, P., and Hill, C.: On the formulation of sea-ice models. Part 1: Effects of different solver implementations and parameterizations, Ocean Model., 33, 129-144, 2010.

Marshall, J., Adcroft, A., Hill, C., Perelman, L., and Heisey, C.: A finite-volume, incompressible Navier Stokes model for studies of the ocean on parallel computers, J. Geophys. Res., 102, 57535766, 1997.

Maslanik, J., Serreze, M., and Barry, R.: Recent decreases in Arctic summer ice cover and linkages to atmospheric circulation anomalies, Geophys. Res. Lett., 23, 1677-1680, https://doi.org/10.1029/96GL01426, 1996.

Maslanik, J., Lynch, A., Serreze, M., and Wu, W.: A case study of regional climate anomalies in the Arctic: performance requirements for a coupled model, J. Climate, 13, 383-401, https://doi.org/10.1175/15200442(2000)013<0383:ACSORC>2.0.CO;2, 2000.

MITgcm Group: MITgcm User Manual, Online documentation, MIT/EAPS, Cambridge, MA 02139, USA, available at: http:// mitgcm.org/public/r2_manual/latest/online_documents (last access: 1 August 2014), 2014.

OSI-SAF: EUMETSAT Ocean and Sea Ice Satelitte Application Facility, Global sea ice concentration reprocessing dataset 19782009 (v1.1, 2011), available at: http://osisaf.met.no (last access: 1 August 2014), 2013.

Pfaffling, A., Haas, C., and Reid, J. E.: A direct helicopter EM sea ice thickness inversion, assessed with synthetic and field data, Geophysics, 72, F127-F137, 2007.

Polyakov, I. V., Pnyushkov, A. V., Alkire, M. B., Ashik, I. M., Baumann, T. M., Carmack, E. C., Goszczko, I., Guthrie, J., Ivanov, V. V., Kanzow, T., Krishfield, R., Kwok, R., Sundfjord, A., Morison, J., Rember, R., and Yulin, A.: Greater role for Atlantic inflows on sea-ice loss in the Eurasian Basin of the Arctic Ocean, Science, 0036-8075, https://doi.org/10.1126/science.aai8204, 2017.

Preußer, A., Heinemann, G., Willmes, S., and Paul, S.: Circumpolar polynya regions and ice production in the Arctic: results from MODIS thermal infrared imagery from 2002/2003 to 2014/2015 with a regional focus on the Laptev Sea, The Cryosphere, 10, 3021-3042, https://doi.org/10.5194/tc-10-3021-2016, 2016.

Rabenstein, L., Krumpen, T., Hendricks, S., Koeberle, C., Haas, C., and Hoelemann, J. A.: A combined approach of remote sensing and airborne electromagnetics to determine the volume of polynya sea ice in the Laptev Sea, The Cryosphere, 7, 947-959, https://doi.org/10.5194/tc-7-947-2013, 2013.
Ricker, R., Hendricks, S., Girard-Ardhuin, F., Kaleschke, L., Lique, C., Tian-Kunze, X., Nicolaus, M., and Krumpen, T.: Satellite-observed drop of Arctic sea ice growth in winter 2015-2016, Geophys. Res. Lett., 44, 3236-3245, https://doi.org/10.1002/2016GL072244, 2017.

Rozman, P., Hölemann, J., Krumpen, T., Gerdes, R., Köberle, C., Lavergne, T., Adams, S., and Girard-Ardhuin, F.: Validating satellite derived and modelled sea-ice drift in the Laptev Sea with in situ measurements from the winter of 2007/08, Polar Res., 30, 7218, https://doi.org/10.3402/polar.v30i0.7218, 2011.

Saha, S. E. A.: The NCEP Climate Forecast System Reanalysis, B. Am. Meteorol. Soc., 91, 1015-1057, https://doi.org/10.1175/2010BAMS3001.1, 2010.

Saha, S. E. A.: The NCEP Climate Forecast System Version 2, J. Climate, 27, 2185-2208, https://doi.org/10.1175/JCLI-D-1200823.1, 2014

Selyuzhenok, V., Krumpen, T., Mahoney, A., Janout, M., and Gerdes, R.: Seasonal and interannual variability of fast ice extent in the southeastern Laptev Sea between 1999 and 2013, J. Geophys. Res.-Oceans, 120, 7791-7806, https://doi.org/10.1002/2015JC011135, 2015.

Serreze, M. C.: Climatological aspects of cyclone development and decay in the Arctic, Atmos.-Ocean, 33, 1-23, https://doi.org/10.1080/07055900.1995.9649522, 1995.

Serreze, M. C., Box, J. E., Barry, R. G., and Walsh, J. E.: Characteristics of Arctic synoptic activity, 1952-1989, Meteorol. Atmos. Phys., 51, 147-164, https://doi.org/10.1007/BF01030491, 1993.

Spreen, G., Kwok, R., and Menemenlis, D.: Trends in Arctic sea ice drift and role of wind forcing: 1992-2009, Geophys. Res. Lett., 38, 19, https://doi.org/10.1029/2011GL048970, 2011.

Steele, M. and Ermold, W.: Loitering of the retreating sea ice edge in the Arctic Seas, J. Geophys. Res., 120, 7699-7721, https://doi.org/10.1002/2015JC011182, 2015.

Tian-Kunze, X., Kaleschke, L., Maßß, N., Mäkynen, M., Serra, N., Drusch, M., and Krumpen, T.: SMOS-derived thin sea ice thickness: algorithm baseline, product specifications and initial verification, The Cryosphere, 8, 997-1018, https://doi.org/10.5194/tc8-997-2014, 2014.

Tian-Kunze, X., Kaleschke, L., and Maaß, N.: SMOS Daily sea ice thickness version 3, ICDC, University of Hamburg, Germany, Digital media, available at: icdc.cen.uni-hamburg.de (last access: 1 August 2014), 2017.

Tschudi, M., Fowler, C., Maslanik, J., Stewart, J. S., and Meier, W.:Polar Pathfinder Daily $25 \mathrm{~km}$ EASE-Grid Sea Ice Motion Vectors. Version 3. [indicate subset used]. Boulder, Colorado USA: National Snow and Ice Data Center, https://doi.org/10.5067/O57VAIT2AYYY (last acess: 1 August 2014), 2016.

Zwally, H., Schutz, B., Abdalati, W., Abshire, J., Bentley, C., Brenner, A., Bufton, J., Dezio, J., Hancock, D., Harding, D., Herring, T., Minster, B., Quinn, K., Palm, S., Spinhirne, J., and Thomas, R.: ICESat's laser measurements of polar ice, atmosphere, ocean, and land, J. Geodyn., 34, 405-445, https://doi.org/10.1016/S0264-3707(02)00042-X, 2002. 